\title{
Sustainability of Water Resources in the
}

\section{Fractured-Rock Area of Maryland}

The 2008 Final Report of the Advisory Committee on the Management and Protection of the State's Water Resources recommended that the State conduct a comprehensive study of the water-supply resources of the fractured-rock area of Maryland to provide the data and scientific tools needed to ensure that water is allocated and used in a sustainable fashion, without causing ecological damage. Through funding and support from the Maryland Department of the Environment (MDE), the Maryland Department of Natural Resources' Maryland Geological Survey (MGS), and the U.S. Geological Survey (USGS), this assessment will begin in 2009.

\section{Water Resources of the Fractured-Rock Area of Maryland}

$\mathrm{T}$ he fractured-rock area of Maryland encompasses the region of the State west of the Fall Line, which is approximated by the Interstate 95 corridor. It includes the Piedmont, Blue Ridge, Ridge and Valley, and Appalachian Plateau Physiographic Provinces (fig. 1). Surface water and ground water are important and interconnected water sources in this area. Streamflow characteristics vary in response to different land use, geology, topography, soil, and other factors. Ground-water flow is quite localized, tending to be controlled by local watersheds. Water in this region moves down through the soil and decomposed rock (saprolite) and along joints, faults, and fractures in the underlying rock (fig. 2). Water availability depends upon the size of fractures as well as the interconnections between fractures.

\section{Why is this assessment necessary?}

\section{Water resources in the area are very vulnerable during drought.}

Unlike in the Maryland Coastal Plain, ground water in the fractured-rock area of Maryland is found mostly under water-table conditions. As a result, ground-water levels rise and fall in response to seasonal precipitation. During periods of drought, ground-water levels can drop rapidly, particularly if drought occurs in the winter and spring, when most aquifer recharge occurs (fig. 3). Many wells in the region went dry during the droughts in 1999 and 2002, and some towns were forced to consider alternative water sources as declining ground-water levels threatened municipal water supplies. Because ground water is the source of stream base flow and critical to maintaining flows during summer and autumn months, declining ground-water levels can cause streams to go dry. An assessment of the fractured-rock water resources will increase our knowledge of aquifer recharge and discharge processes. This will provide water managers, policy makers, and planners with a sound basis for determining how much water is potentially available for future growth, and help them weigh the costs and benefits of current water management practices against alternatives.

\section{Better information and tools are needed to estimate the availability of water.}

Water regulators, planners, and policy makers need to know how much water can be withdrawn from wells and streams without causing adverse impacts to the resource or other users. Studying the effects of water withdrawals may indicate that the cumulative impacts of increased population growth combined with other consumptive uses are resulting in adverse impacts or highlight specific areas of Maryland's fractured-rock terrain that are more susceptible to adverse impacts from consumptive uses. Conversely, investigation may show that current allocation methods are not resulting in adverse impacts and are sufficiently protective of the resources. Both ground- and surfacewater appropriations are assessed using streamflow statistics; however, since most streams do not have stream gages, streamflow statistics for a particular watershed are usually

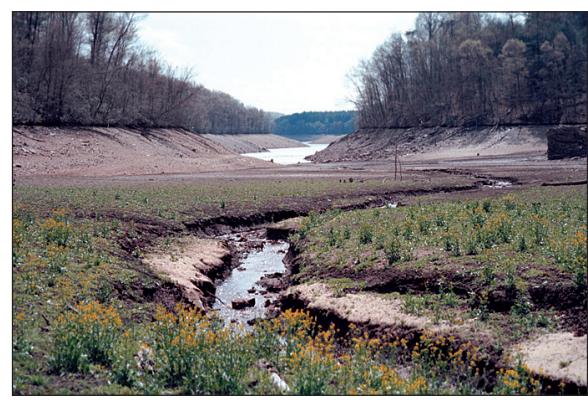

Drought conditions in Prettyboy Reservoir, April 2002. Photograph by USGS.

estimated from a gaged watershed with similar characteristics. This project will provide new tools, such as StreamStats (Ries and others, 2008), that can more accurately estimate these statistics for ungaged streams, resulting in better-informed permitting decisions.

Current methodologies evaluate one permit request at a time; tools need to be developed that can assess the cumulative effects of multiple withdrawals on a watershed. Accurate estimates of consumptive water use (water that is not returned to the watershed where it originated) are also needed. Finally,

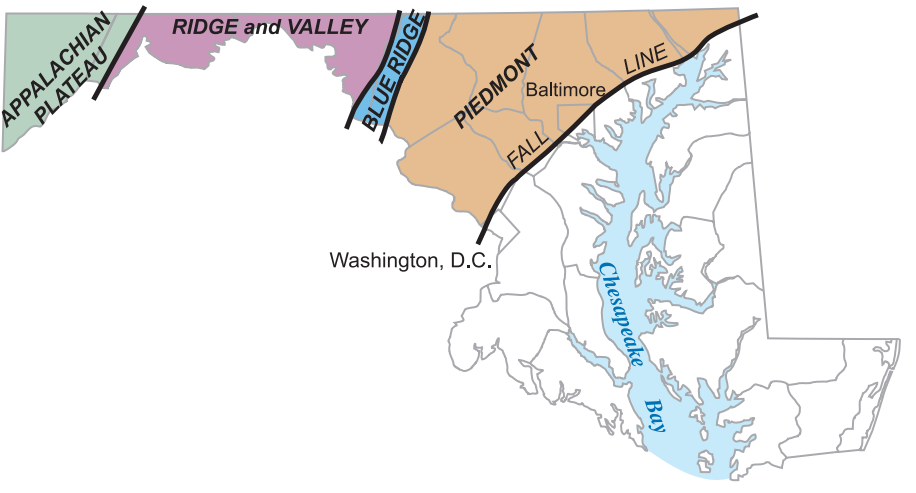

Figure 1. Fractured-rock area of Maryland (includes the Piedmont, Blue Ridge, Ridge and Valley, and Appalachian Plateau Physiographic Provinces) (modified from Maryland Geological Survey). 
these tools and water data need to be incorporated into an integrated water-information system that can be efficiently and accurately employed to make informed decisions on water appropriation.

\section{Minimum stream flow-by requirements} need to be evaluated to determine if they are adequate to maintain the ecological integrity of Maryland's streams.

Water managers and planners need better information about when a water withdrawal is likely to impact the stream ecology. Currently, surface-water users are permitted to withdraw water only if the streamflows remain above minimum flow-by requirements to ensure that adequate water remains in the stream for human use and healthy stream ecology. However, different minimum streamflows may be needed to maintain the ecological integrity of a stream and the health of aquatic biota. Using data collected by the Department of Natural Resources (MD DNR) for the Maryland Biological Stream Survey, this study will assess the adequacy of statistically determined stream flow-by amounts. Research watersheds will also be established and studied in combination with this assessment.

\section{Hydrologic and geologic factors related to water supply need to be assessed.}

In order to prudently manage the water resources of the fractured-rock area of Maryland, it is necessary to understand the hydrologic processes involved in the storage, movement, and use of water within and between watersheds. This project will study how different factors affect the availability of water, such as variations in saturated saprolite thickness, saprolite characteristics, rock type, and impervious land cover. Studying these processes will involve analyzing existing data in combination with the research watersheds for integrated hydrologic monitoring.

\section{Goals of the Assessment}

- Develop a comprehensive database of streamflow, hydrogeologic, wateruse, and other appropriate surfacewater and ground-water information.

- Develop a statistically based software tool to estimate water availability.

- Determine streamflow requirements for aquatic organisms in streams in different settings.

- Determine the factors affecting ground-water availability in different hydrogelogic settings.

- Assess watershed processes in different settings by establishing research watersheds.
Plans for a Comprehensive Assessment of Water Resources in the Fractured-Rock Area of

A 5-year study plan has been developed jointly by MDE, MD DNR, and USGS. Products planned for this assessment will include:

- geospatial data sets of streamflow, hydrogeology, water use, and other appropriate information; water availability in watersheds that lack stream gages; Maryland

- software that can be used to estimate

- a digital atlas of water use and water availability for the fractured-rock area of Maryland; and

- watershed-based fact sheets describing water withdrawals, availability, and other information for selected watersheds.

Start-up of the fractured-rock waterresources assessment is planned for early 2009, with MDE, MD DNR, and USGS providing financial and technical support for the project. Significant funding for the completion of the entire assessment will be required from current and additional partners over the next 5 years.

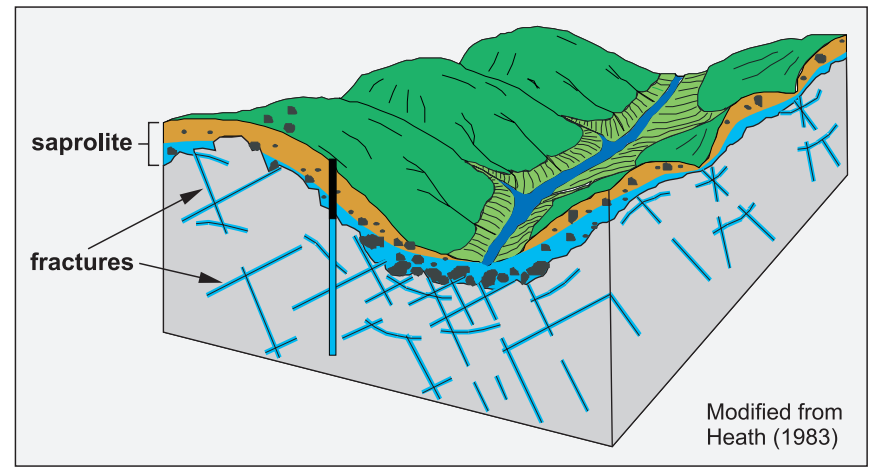

Figure 2. Cross section showing saprolite and fractured-rock system in crystalline rocks.

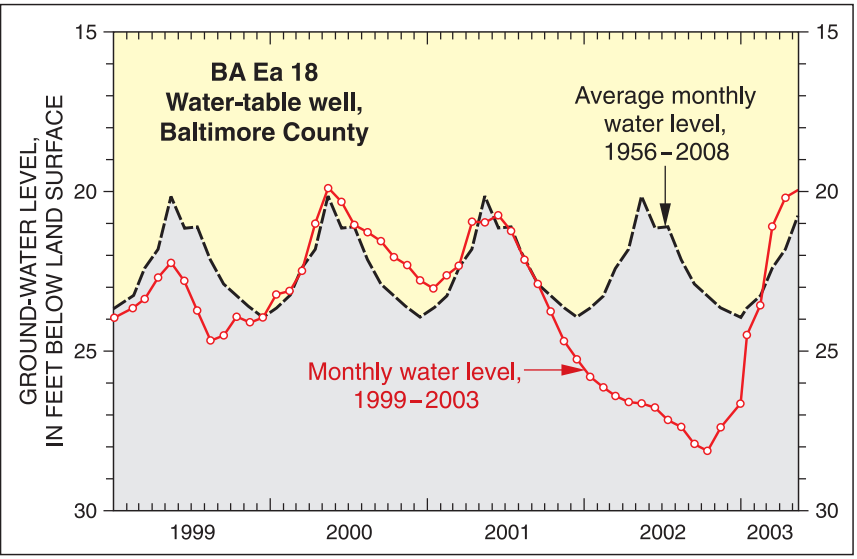

Figure 3. Hydrograph showing ground-waterlevel fluctuation in relation to precipitation. Note drop in water level during 2002 drought.

\section{References}

Heath, R.C., 1983, Basic ground-water hydrology: U.S. Geological Survey Water Supply Paper 2220, 84 p.

Ries, K.G. III, Guthrie, J.D., Rea, A.H, Steeves, P.A., and Stewart, D.W., 2008, StreamStats: A water resources web application: U.S. Geological Survey Fact Sheet 2008-3067, 6 p.

State of Maryland, 2008, Water for Maryland's future: What we must do today, Final Report of the Advisory Committee on the Management and Protection of the State's Water Resources: Prepared by the Maryland Department of the Environment, $32 \mathrm{p}$.

\section{Authors}

David W. Bolton

Maryland Geological Survey

Maryland Department of Natural Resources 2300 St. Paul Street

Baltimore, MD 21218

(dbolton@dnr.state.md.us)

MARYLAND

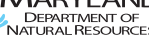

James M. Gerhart

U.S. Geological Survey

5522 Research Park Drive

Baltimore, MD 21228

(jgerhart@usgs.gov)

ॠUSGS

Saeid Kasraei

Maryland Department of the Environment

1800 Washington Blvd.

Baltimore, MD 21230

(skasraei@mde.state.md.us) 